\title{
Impact of Incorporating NIR Reflective Pigments in Finishing Coatings of ETICS
}

\author{
Nuno M. M. $\operatorname{Ramos}^{1, *(D)}$, Joana Maia ${ }^{1} \mathbb{D}$, Andrea R. Souza ${ }^{1}$, Ricardo M. S. F. Almeida ${ }^{2}$ and Luís Silva $^{3}$ \\ 1 CONSTRUCT—LFC, Faculty of Engineering, University of Porto, 4200-465 Porto, Portugal; \\ joanamaia@fe.up.pt (J.M.); andrea.souza@fe.up.pt (A.R.S.) \\ 2 Department of Civil Engineering, Polytechnic Institute of Viseu, 3504-510 Viseu, Portugal; \\ ralmeida@estgv.ipv.pt \\ 3 Saint-Gobain Weber, Zona Industrial da Taboeira-Esgueira, 3800-055 Aveiro, Portugal; \\ luis.silva@saint-gobain.com \\ * Correspondence: nmmr@fe.up.pt
}

Citation: Ramos, N.M.M.; Maia, J.; Souza, A.R.; Almeida, R.M.S.F.; Silva, L. Impact of Incorporating NIR Reflective Pigments in Finishing Coatings of ETICS. Infrastructures 2021, 6, 79. https://doi.org/ $10.3390 /$ infrastructures6060079

Academic Editor: Maria do Rosário Veiga

Received: 30 April 2021

Accepted: 23 May 2021

Published: 25 May 2021

Publisher's Note: MDPI stays neutral with regard to jurisdictional claims in published maps and institutional affiliations.

Copyright: (c) 2021 by the authors. Licensee MDPI, Basel, Switzerland. This article is an open access article distributed under the terms and conditions of the Creative Commons Attribution (CC BY) license (https:// creativecommons.org/licenses/by/ $4.0 /)$.

\begin{abstract}
Near-infrared (NIR) reflective materials are being developed for mitigating building cooling needs. Their use contributes to broadening the range of colours, responding to the urban aesthetic demand without compromising the building performance. Despite the increase in NIR reflective pigments investigation, there is still a knowledge gap in their applicability, impact, and durability in multilayer finishing coatings of External Thermal Insulation Composite Systems (ETICS). Hence, the main goal of this work consists of evaluating the impact of incorporating NIR reflective pigments (NRP) in the solar reflectance of the surface layer of ETICS, without affecting the colour perception, as well as their influence on the colour durability and surface temperature. As such, colour, solar reflectance, and surface temperature were monitored for 2 years in dark-coloured specimens of ETICS, with and without NRP and a primer layer. It was confirmed that the main contribution of NRP is the increase of solar reflectance and, consequently, the decrease in surface temperature, especially for high exterior temperatures (around $30^{\circ} \mathrm{C}$ ). Moreover, these pigments highly increase the NIR reflectance without affecting the visible colour. In addition, they contribute to maintaining the colour characteristics. The application of primer increased the surface temperature, especially for higher exterior temperatures. However, it contributes to a lower colour difference and solar reflectance variation, which is an important achievement for durability purposes.
\end{abstract}

Keywords: solar reflectance; surface temperature; colour; ETICS; NIR reflective pigments

\section{Introduction}

The use of thermal insulation materials is an effective way of reducing heat losses in buildings by decreasing the thermal transmittance through the envelope [1]. In addition, new eco-efficient materials and technologies are being developed to mitigate buildings' cooling demand [2-4].

The ETICS (External Thermal Insulation Composite System) is one of the most widely used thermal façade systems, and its performance has been studied by different authors [5-7]. This technology is quite popular in the building industry, presenting positive aspects such as the reduction of thermal bridges and the ability to be easily applied in façade refurbishment. However, pathologies related to finishing coatings, especially microcracking and algae growth, can occur and were observed in various studies [8-10]. The degradation agents, which affect the ETICS coating, include solar radiation, temperature and relative humidity fluctuations, and the action of rain. These agents can produce colour changes, staining, and cracking [11,12]. To prevent part of these pathologies, the old guideline ETAG 004 [13] defines $80^{\circ} \mathrm{C}$ as the maximum temperature recommended for the ETICS surface. However, the new European Assessment Document EAD 040083-000404 [14], which replaces the ETAG 004, did not refer to this recommendation. In addition, 
the European Guideline for the application of ETICS [15] recommends a minimum solar reflectance between 0.2 and 0.3 (depending on the climatic conditions). These restrictions have led to the frequent use of light colours in façades with ETICS. Daniotti et al. [16] evaluated the effect of thermal shock through the analysis of the number of events that occur in a certain period in which there is a variation of the surface temperature between $4{ }^{\circ} \mathrm{C}, 5^{\circ} \mathrm{C}$, and $10^{\circ} \mathrm{C}$ in one hour. It was found that ETICS with solar absorption values of 0.80 had an occurrence of 2000 events per year, for a surface temperature variation of $4{ }^{\circ} \mathrm{C} / \mathrm{h}$, and 300 events/year for a surface temperature variation of $10{ }^{\circ} \mathrm{C}$ in one hour. While considering a solar absorption of 0.60 , the number of events is considerably lower (more than 500 events).

It is considered that approximately $99 \%$ of solar radiation comprises wavelengths between 300 and $2500 \mathrm{~nm}$, which is called the solar spectrum [17]. Therefore, it is important to measure the reflectance of the surfaces over the entire solar spectrum, as this is a function of the wavelength of the incident radiation, also depending on other factors such as the angle of the incident radiation, the colour, and the roughness of the surfaces, among others [18]. As the solar spectrum includes visible light (Vis), ultraviolet (UV) and infrared (IR) radiation, different possibilities of reducing solar absorption by building surfaces can be explored by the industry.

Cool materials are defined as having high solar reflectance and high infrared emittance [19]. Various scientific contributions that have been developed since the 1970s demonstrated that cool coatings can significantly improve indoor and outdoor thermal comfort while reducing the buildings' energy consumption [20]. A technology that is already being commercially applied is the introduction of near-infrared reflective (NIR) pigments that reduce the overall solar absorption of the surface [2,21,22]. If this type of cool pigments can be used in ETICS as part of its multilayer finishing system, the range of colours could be broadened, providing a positive answer to the urban aesthetic request for darker colours and complementing the current white-cool solutions. The incorporation of high reflectance pigments in the finishing coatings of ETICS can produce impacts on its solar reflectance, surface temperature, and colour degradation. The ETICS finishing will usually correspond to a rough surface between 0.4 and $1 \mathrm{~mm}$ [23] that in practical applications may present a sensitive heterogeneity regarding optical and thermal properties.

It is widely accepted [24-26] that the optical properties and the scattering ability of the cool coated surface is mainly affected by the particle size and the refractive index of the oxides combined on layers coating $[27,28]$. Therefore, several studies were carried out to optimize the use of nanoparticles in cool coatings. The properties of powder cool pigments were evaluated on Levinson et al. [24] and Jose et al. [29] for different colours and oxides particles.

Paints based on acrylonitrile styrene acrylate (ASA) doped with barium titanate $\left(\mathrm{BaTiO}_{3}\right)$, calcium molybdate $\left(\mathrm{CaMoO}_{4}\right)$, yttrium oxide $\left(\mathrm{Y}_{2} \mathrm{O}_{3}\right)$, and antimony oxide $\left(\mathrm{Sb}_{2} \mathrm{O}_{3}\right)$ were studied by Xiang et al. [30] and Xiang and Zhang [31]. Acrylic latex-based incorporated by $\mathrm{TiO}_{2}$ was developed by several authors [32-34], and the cool properties of acrylic paints incorporated with cool commercial pigments were evaluated by Uemoto et al. [35]. Another variety of coatings as cement-based materials [36], hydrophobic products [37], and polyester [38], doped with $\mathrm{TiO}_{2}$, are also being developed and investigated.

The durability and life-cycle of buildings highly depend on the material properties and environmental conditions regarding their long-term performance [39]. This takes even more importance when observing the climate changes and their impact on the built environment $[40,41]$. Several studies already focus on the effect of these materials on the surface temperature of buildings envelopes, especially in the summer season where their positive effect is more obvious. The life-cycle $[42,43]$ and durability performance $[44,45]$ of cool coatings have been studied by many authors with a focus on roofs, which together produced the fundamental results of an international standard elaboration such as the ASTM D 7897 [46]. 
As analysed in Pisello [20], cool coating investigation is rapidly increasing its impact within the scientific community. Nevertheless, there is still a knowledge gap in the applicability of cool materials and their durability when applied to building components.

This gap is even more evident when considering the multilayer finishing coating adopted in ETICS. Hence, the main goal of this work consists of evaluating the impact of incorporating NIR reflective pigments (NRP) in the solar reflectance, without affecting the colour perception, as well as their influence on the colour durability and surface temperature.

\section{Methodology}

\subsection{Experimental Procedure}

This study is focused on the evaluation of the impact of the incorporation of NIR Reflective Pigments (NRP) in finishing coatings of ETICS. To that end, measurements of colour, solar reflectance, and surface temperature were carried out between May of 2017 and May of 2019 (Month 0 to Month 24). Except for the surface temperature, which was monitored continuously, the remaining properties were measured once a year in May. The tests were carried out on a roof of the Civil Engineering Department of the University of Porto. Figure 1 presents the main climatic conditions during the experimental procedure as well as the timeline of measurements. The air temperature distribution is shown using box-plot charts, while the global solar radiation is represented by the monthly average values and the precipitation by monthly accumulated values. These data values were provided by IPMA (Portuguese Institute for Sea and Atmosphere) from a weather station located nearby the experiment.

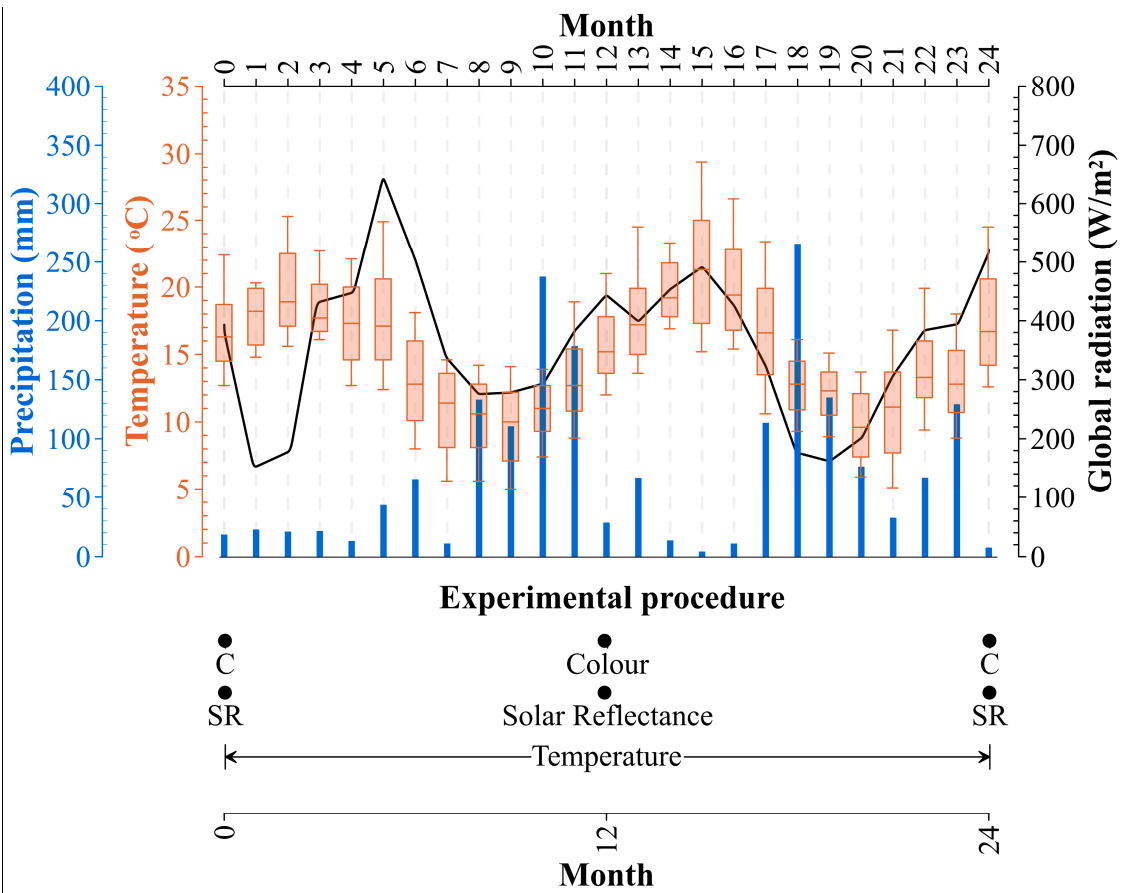

Figure 1. Timeline of the experimental procedure and climatic conditions (source: IPMA).

The evaluation of solar reflectance was carried out using two methods and equipment: a pyranometer (method E 1918A) and a spectrophotometer. The method E 1918A, proposed by Akbari and Levinson [47], consists of an adaptation of the ASTM E1918 Standard Test Method for Measuring Solar Reflectance of Horizontal and Low-sloped Surfaces in the Field [18]. The E 1918A method uses a pyranometer to measure the radiant solar energy that is incident and the energy that is reflected at the surface per unit time and unit area. However, unlike the original procedure that is indicated for large surfaces, this method allows the measurement of square surfaces with an area of $1 \mathrm{~m}^{2}$. Different authors 
compared distinct methods of solar reflection measurement, and the E 1918A method showed reliable results [48,49].

In the tests carried out in this work, an SR05 Hukseflux Thermal Sensors pyranometer was used, which presents an estimated precision of 4.4\% [50]. This pyranometer meets the requirements of the second class of ISO 9060 [51].

Complementary to the measurement of total solar reflectance with the pyranometer, a spectrophotometer was used to evaluate the spectral reflection (UV-Vis and NIR spectrum regions). The diffuse solar reflectance was measured using a modular UV-Vis/NIR spectrophotometer: FLAME-T and FLAME-NIR Ocean Optics. This modular spectrophotometer combines a light source of tungsten-halogen and deuterium lamps (DH-200 Ocean Optics) delivered to a $4.5 \mathrm{~mm}$ fibber diameter port. The optical fibre emits a beam to the specimen, and the reflected light beam is read. The output of the test is the diffuse reflectance spectrum, which is measured at $10 \mathrm{~nm}$ wavelength intervals ranging from 190 to $1650 \mathrm{~nm}$. The result of spectral reflection is expressed with the solar reflectance (SR) calculated by Equation (1) [52].

$$
\mathrm{SR}=\frac{\sum_{i=1}^{n} R\left(\lambda_{i}\right) E_{\lambda i} \Delta \lambda_{i}}{\sum_{i=1}^{n} E_{\lambda i} \Delta \lambda_{i}}
$$

where $\mathrm{R}$ is the measured diffuse spectral reflectivity, $\lambda$ is the wavelength (nm) and $E_{\lambda}$ is the spectral irradiance of the sun at the earth surface $\left(\mathrm{W} /\left(\mathrm{m}^{2} \mathrm{~nm}\right)\right)$, according to the ASTM Standard G-173 [17]. The reflectance regions are defined by Equation (2).

$$
\mathrm{SR}=0.05 \mathrm{UV}+0.42 \mathrm{Vis}+0.53 \mathrm{NIR}
$$

The surface temperature was measured using T-type thermocouples with a standard metal combination (Copper Alloys and Constantan Alloys), connected to a Technetics Mikromec Logger Multisens. The measuring accuracy is $0.2^{\circ} \mathrm{C}$.

The colour was evaluated using the CIELab coordinate system $\left(\mathrm{L}^{*}, \mathrm{a}^{*}\right.$ and $\left.\mathrm{b}^{*}\right)$ according to ISO 1164-4 [53]. The CIELab coordinate system can be used to describe the colour and lightness of a reflecting surface normalised to the colour of the light source (if the reflecting surface has the same colour as the light source then $\mathrm{a}^{*}$ and $\mathrm{b}^{*}$ are zero) [54]. The coordinates of contours $\mathrm{a}^{*}$ and $\mathrm{b}^{*}$ correspond to the chroma and hue, and the $\mathrm{L}^{*}$ represents the lightness. The lightness coordinate varies between 0 and 100, where zero is black and 100 is white. The contours vary from $-a^{*} b^{*}$ to $+a^{*} b^{*}$, where a negative $a^{*}$ corresponds to green and positive to red tones, and the negative $b^{*}$ corresponds to blue and the positive corresponds to yellow tones [55]. The CIELAB parameters also allow the calculation of colour differences [56-58]. This colour difference $-\Delta \mathrm{E}-$ reflects how the human eye perceives the colour difference, and it is calculated using the geometric coordinates $L^{*} a^{*} b^{*}$.

The colour was analysed using a Konica Minolta's CR-10 Tristimulus portable Colorimeter. The equipment measures the $\mathrm{L}^{*}, \mathrm{a}^{*}, \mathrm{~b}^{*}$, and $\mathrm{dE}^{*}$ in an area of $8 \mathrm{~mm}$. All colour measurements are taken using conditions of the standard illuminant D65 and 10 degrees observer. The measuring range is $\mathrm{L}^{*} 10$ to 100 with a standard deviation within $\Delta \mathrm{E}^{*} \mathrm{ab}$ 0.1 and operates between 0 and $40{ }^{\circ} \mathrm{C}$ of temperature and $85 \%$ or less of relative humidity (at $35^{\circ} \mathrm{C}$ ) with no condensation.

\subsection{Materials}

The proposed methodology was applied to 5 ETICS specimens with $1 \mathrm{~m}^{2}: 3$ constituted by 3 layers, and 2 constituted by 4 layers. The difference between the two sets is that primer was only applied in 2 specimens. Figure 2 shows a schematic representation of the constitution of the specimens and their placement. 


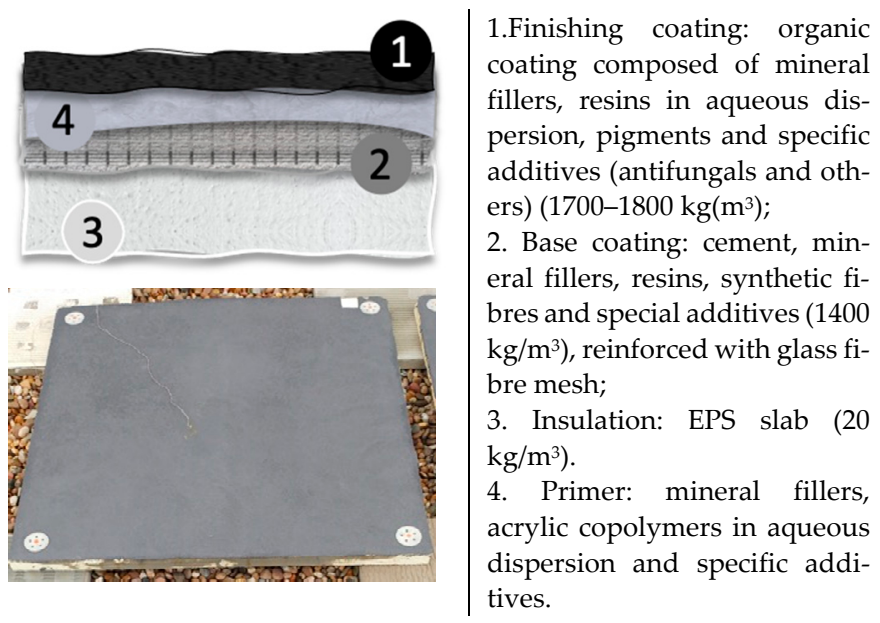

Figure 2. Constitution of the specimens and placement "in situ" (only specimens with primer have layer 4).

The finishing coating consists of a thin layer of a commercial material of approximately $2 \mathrm{~mm}$, with $3 \%$ of $\mathrm{TiO}_{2}$ incorporation. The primer is a thin black layer (between 0.1 and $0.15 \mathrm{~mm}$ ) with the incorporation of $\mathrm{TiO}_{2}$. The base coating is applied in two layers of $1.5 \mathrm{~mm}$ with a glass fibre mesh between them. The EPS insulation slab layer has a thickness of $4 \mathrm{~cm}$.

Table 1 includes a detailed description of the constitution of the 5 specimens. Regarding the designation of the specimens, " $\mathrm{P}$ " stands for primer, "W" stands for the white colour, and "NR" stands for the incorporation of NIR Reflective Pigments (NRP). Only one specimen is white, and the remaining are black. The white (W) and black (S) are reference specimens, without NIR reflective pigments and primer. These specimens are important to establish benchmarks in the colour range comparison.

Table 1. Constitution of the specimens.

\begin{tabular}{cccc}
\hline Specimen & Primer & NIR Finishing Coating & Description \\
\hline S & & & Standard black (reference) \\
\hline PS & $\bullet$ & $\bullet$ & Standard black with primer \\
\hline NR & $\bullet$ & $\bullet$ & NIR Black \\
\hline PNR & & & White (reference) \\
\hline W & & &
\end{tabular}

To evaluate the effect of the NIR reflective pigments, the black specimens have two different constitutions regarding the pigment incorporated in the finishing coating. Specimen "S" includes a standard colourant-ferroso-ferric oxide dispersion, colour index PBk11, with 48\% pigment content-and specimen NR incorporates a NIR reflective colourant-chrome iron oxide dispersion, colour index PBr29, with 74\% pigment content. The colourants were incorporated in $6 \%$ of volume in addition to the finishing coating.

\section{Results and Discussion}

\subsection{Colour}

The CIELab colour coordinates were determined following the previously explained procedure. Table 2 presents the results obtained in each specimen. 
Table 2. CIELab colour coordinates.

\begin{tabular}{|c|c|c|c|c|c|}
\hline \multirow{2}{*}{$\begin{array}{l}\text { Initial } \\
\text { Colour }\end{array}$} & \multirow{2}{*}{ Specimen } & \multirow{2}{*}{ Month } & \multicolumn{3}{|c|}{ CIELab Coordinates ** } \\
\hline & & & $\mathbf{L}^{*}$ & $a^{*}$ & $\mathbf{b}^{*}$ \\
\hline & \multirow{3}{*}{$S$} & 0 & $34.0 \pm 0.17$ & $-0.2 \pm 0.10$ & $-1.5 \pm 0.25$ \\
\hline & & 12 & $33.9 \pm 0.10$ & $-0.1 \pm 0.10$ & $0.0 \pm 0.10$ \\
\hline & & 24 & $35.9 \pm 0.45$ & $-0.5 \pm 0.10$ & $0.4 \pm 0.50$ \\
\hline & \multirow{3}{*}{ PS } & 0 & $33.4 \pm 0.36$ & $0.1 \pm 0.15$ & $-1.0 \pm 0.53$ \\
\hline & & 12 & $33.3 \pm 0.71$ & $-0.2 \pm 0.06$ & $0.0 \pm 0.06$ \\
\hline & & 24 & $34.5 \pm 0.12$ & $0.4 \pm 0.31$ & $1.1 \pm 0.15$ \\
\hline & \multirow{3}{*}{ NR } & 0 & $34.8 \pm 0.62$ & $0.4 \pm 0.06$ & $-2.3 \pm 0.36$ \\
\hline & & 12 & $34.7 \pm 0.84$ & $0.1 \pm 0.15$ & $-1.0 \pm 0.67$ \\
\hline & & 24 & $36.3 \pm 0.21$ & $-0.5 \pm 0.17$ & $-1.2 \pm 0.06$ \\
\hline & \multirow{3}{*}{ PNR } & 0 & $34.1 \pm 0.60$ & $0.7 \pm 0.10$ & $-2.0 \pm 0.31$ \\
\hline & & 12 & $33.5 \pm 0.21$ & $0.5 \pm 0.15$ & $-1.4 \pm 0.30$ \\
\hline & & 24 & $35.5 \pm 0.06$ & $0.3 \pm 0.10$ & $-1.3 \pm 0.26$ \\
\hline
\end{tabular}

** Average and standard deviation (3 measurements).

The lightness indicates the brightness or the tone of the initial colour (Month 0 ) and can be used to compare specimens of the same colour. It is possible to verify that the standard (S) and NIR reflective pigment (NR) specimens have the same brightness, with a maximum difference of $4.8 \%$ between the PS and NR specimens. The primer application (PS and PNR) resulted in lower $\mathrm{L}^{*}$ in comparison with the specimens without primer, which can be explained by the colour of this layer being darker than the base coat. As reported by Revel et al. [59], Coser et al. [60], and Rossi et al. [61], the incorporation of some types of NIR reflective pigments can lead to an increase of $L^{*}$. However, in this study, a black-based coloured pigment was used, which explains the lower lightness difference. Similar results were also found by Cozza et al. [62].

Regarding black colour, $\mathrm{a}^{*}$ and $\mathrm{b}^{*}$ coordinates are expected to be around zero and not presenting a large difference between them (achromatic aspect) [55]. Figure 3 presents the chroma coordinates of the analysed specimens in M0, M12, and M24, considering the specimens with and without (standard) NIR reflective pigments (with and without primer application).

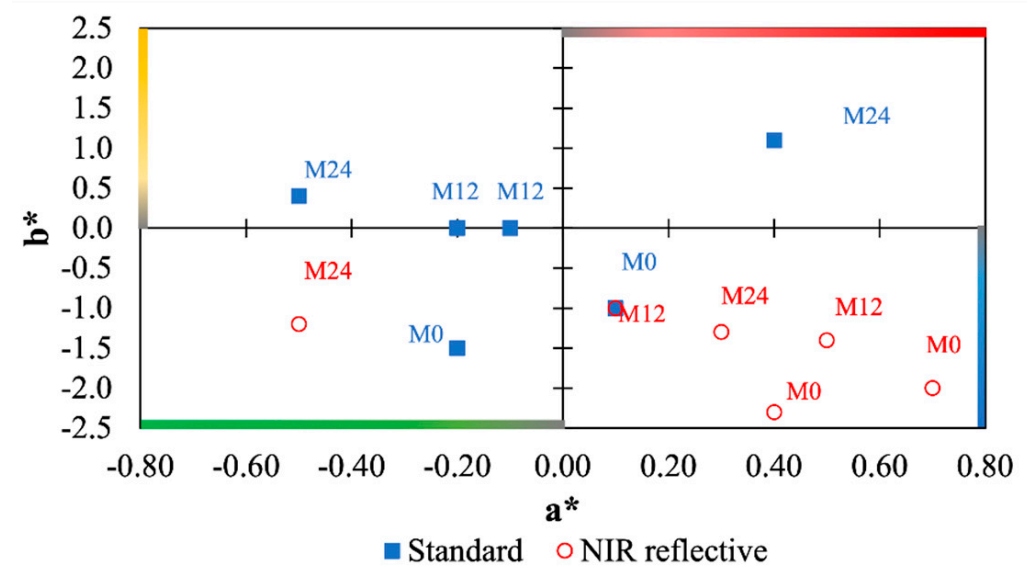

Figure 3. Chroma coordinates.

It is possible to observe in Figure 3 the impact of NIR reflective pigments (NR and PNR) in the colour aesthetic since $a^{*}$ and $b^{*}$ values and the difference between them are higher for the specimens without NIR reflective pigments (S and PS). In addition, the incorporation of NRP leads to a lower variation of the chroma coordinates, which contributes to colour durability. 
The total colour difference $(\Delta \mathrm{E})$ and the lightness difference $(\Delta \mathrm{L})$, calculated for the whole period of analyses (Month 0 to Month 24), are shown in Figure 4.

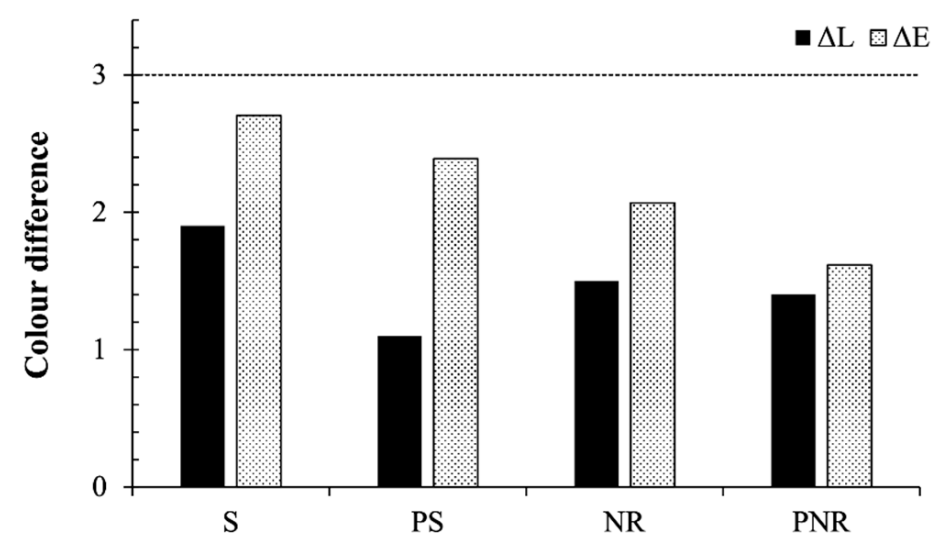

Figure 4. Colour difference between M0 and M24.

The smallest colour difference detectable by the human eye is usually considered as $\Delta \mathrm{E}=1$, but a limit value of 3 was considered, following Cozza et al. [62] and Mokrzycki and Tatol [63]. According to the studies performed by Ihara et al. [64] and Uemoto et al. [35], it was expected that colours with cool properties presented a higher colour degradation in the early years (before three years of exposure). Regardless of that, as can be seen in Figure 4, no specimen achieved the critical value of $\Delta \mathrm{E}$, which could be explained by the incorporation of $\mathrm{TiO}_{2}$ in the formulation of the finishing coating. $\mathrm{TiO}_{2}$ is frequently used as an additive to improve the weathering resistance of polymeric coatings $[60,65,66]$. In addition, the influence of the primer application (PS and PNR) was identified, since a lower colour variation, compared with the specimens without primer (S and NR), was obtained.

It was expected that darker colours presented a fast degradation due to thermal stress and UV degradation regarding high solar absorption [64]. However, as verified in Figure 4, the PNR specimen presented a reduction of $15 \%$ on the $\triangle \mathrm{E}$ compared to the PS, even having a superior lightness variance.

\subsection{Solar Reflectance}

The results of the solar reflectance (SR) obtained by the pyranometer method are presented in Table 3, where the effect of the incorporation of NRP can be identified.

Table 3. Solar reflectance.

\begin{tabular}{cccc}
\hline \multirow{2}{*}{ Specimen } & \multicolumn{3}{c}{ SR (-) * } \\
\cline { 2 - 4 } & Month 0 & Month 12 & Month 24 \\
\cline { 2 - 4 } S & $0.12 \pm 0.007$ & $0.12 \pm 0.009$ & $0.08 \pm 0.011$ \\
PS & $0.11 \pm 0.002$ & $0.12 \pm 0.008$ & $0.08 \pm 0.007$ \\
NR & $0.25 \pm 0.003$ & $0.25 \pm 0.006$ & $0.19 \pm 0.008$ \\
PNR & $0.25 \pm 0.006$ & $0.23 \pm 0.010$ & $0.22 \pm 0.007$ \\
W & $0.62 \pm 0.003$ & $0.61 \pm 0.008$ & $0.47 \pm 0.009$ \\
\hline
\end{tabular}

*Average and standard deviation (3 measurements).

Specimens NR and PNR (with NIR reflective pigments) had an increase of $118 \%$ in comparison to the standard black (S and PS). The improvement resulting from the incorporation of NIR reflective pigments was also stated in several previous studies $[60,65,67,68]$. Generally, the specimens presented a reduction of solar reflectance throughout the exposition period. Figure 5 shows the solar reflectance of the black-coloured specimens regarding the entire period of ageing (Month 0 to Month 24). 


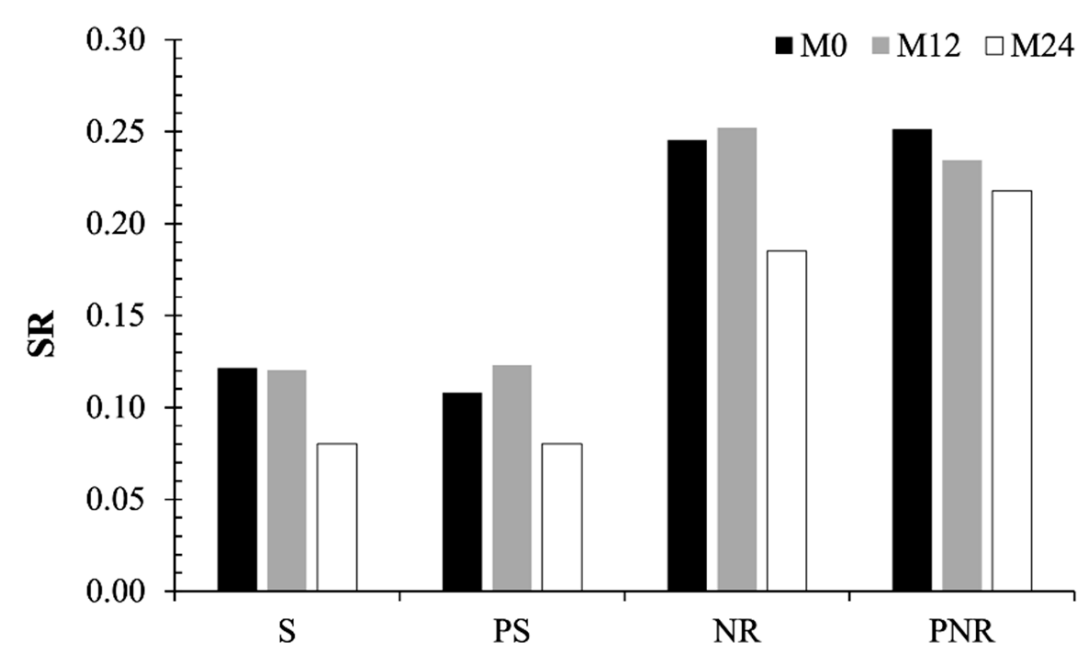

Figure 5. Solar reflectance of the black-coloured specimens in months M0, M12, and M24.

The standard black (S) showed a reduction of 33\% in the solar reflectance, between M0 and M24, while for NR was 25\%. Considering the specimens with primer layer, the difference between M0 and M24 was 25\% and 13\% for PS and PNR, respectively. In both cases, the incorporation of NIR reflective pigments had a positive effect to keep the solar reflectance values. These results are in line with previous studies developed by Paolini et al. [65] and Rosso et al. [69], where a loss of reflectance with the ageing effect was also observed.

A standard black colour should have a spectral reflectance curve, on the Vis region, near to $20 \%$, and colours with NIR reflective pigments should be focussed on the NIR region since it is where their performance is enhanced. The colour variation can affect the reflectance in the visible range of the solar spectrum, which contributes to $42 \%$ of the solar reflectance, according to Equation (2). To evaluate this effect, the contribution of NRP in the different regions was analysed in Month 24 with the aid of a spectrophotometer (see Figure 6).

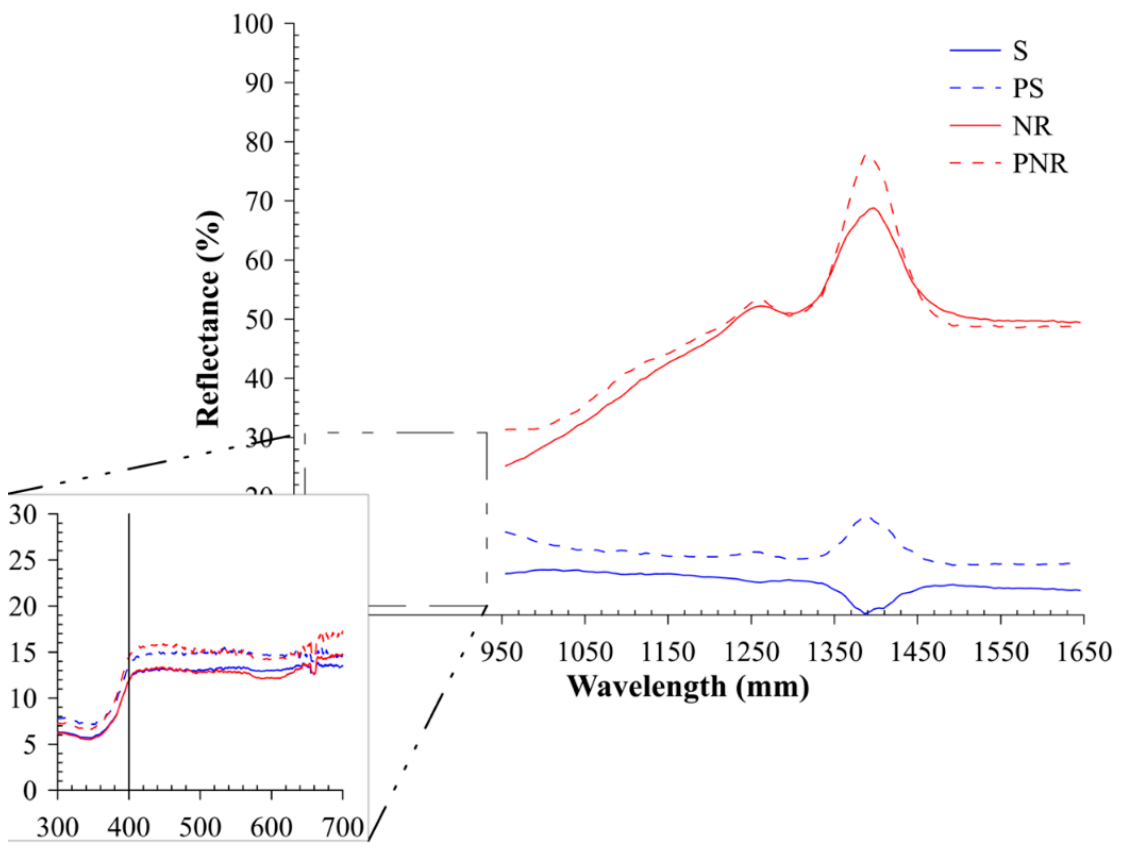

Figure 6. Spectral reflectance. 
Observing the UV-Vis region (small square) is possible to detect a similar behaviour between the specimens, which can indicate that the incorporation of the NRP (blue line) does not affect these reflectance values, lower than $20 \%$, and also the colour (see Table 2). The specimens with NRP (blue line) had higher NIR reflectance than the standard specimens (red line). The primer (dash line) also positively influenced the NIR reflectance.

The diffuse solar reflectance in the solar spectrum regions (UV/Vis/NIR) was calculated according to Equations (1) and (2), and the results are presented in Figure 7.

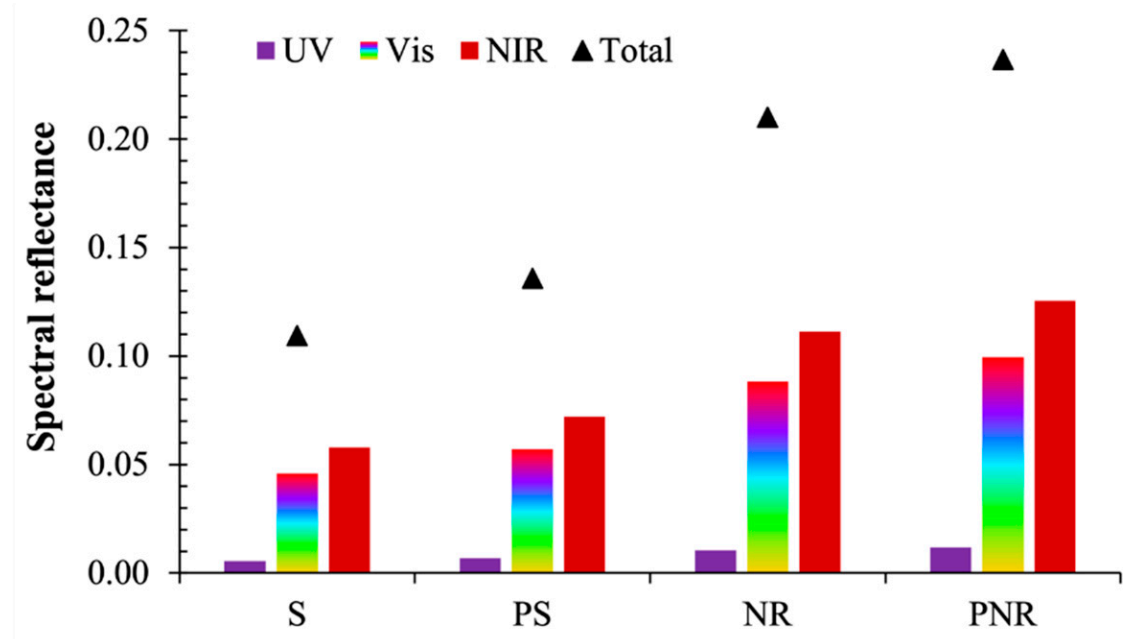

Figure 7. UV-Vis-NIR reflectance.

Since the finishing coating and primer layer incorporate $\mathrm{TiO}_{2}$ particles, which contribute to a lower degradation of polymeric-based materials due to UV radiation [65,66], low values of UV reflectance were observed. These results and the colour parameters (in Table 2) confirmed this effect.

The Vis reflectance is related to the visible colour of the finishing coating. Consequently, light colours will have a higher reflectance in this region at the same time that the NIR reflectance will significantly affect the absorbed solar energy. Several studies stated that black colours should present a Vis reflectance near to 0.2 [62,70-72]. It could be observed that the specimens with NIR reflective pigments (NR and PNR) presented Vis reflectance $\approx 0.1$, confirming that the colour does not change due to the pigment incorporation. Analysing the spectral behaviour, a higher variation of NIR reflectance was expected, comparing to the Vis region: an increment of $91 \%$ in NR, comparing to S, and $73 \%$ between PS and PNR.

The correlation between the diffuse reflectance (spectrophotometer) and solar reflectance (pyranometer) is shown in Figure 8.

The good correlation between the results $\left(R^{2}>0.9\right)$ confirmed that the diffuse reflectance of rough coatings contributes to practically all solar reflectance, which was also verified by Zinzi et al. [73] and Meola et al. [74]. 


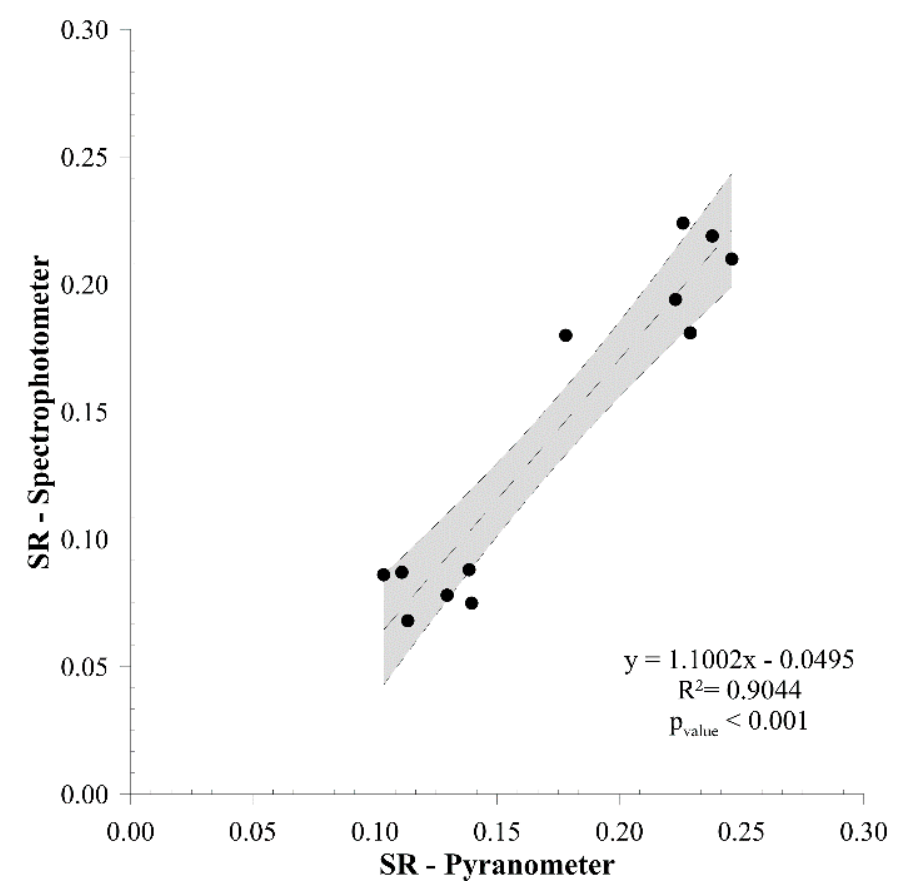

Figure 8. Correlation between spectrophotometer and pyranometer measured reflectance.

\subsection{Surface Temperature}

The surface temperature of each specimen and the exterior temperature (Te) were analysed. Since the NRP impact is enhanced with high temperatures, two distinct and representative (of the most usual behaviour) periods were considered: mild (during M12) and high temperatures (M13).

As expected, the higher the exterior temperature, the higher the surface temperatures and the differences between the different specimens (see Figure 9). In both mild and hot periods, the benefits of raising the solar reflection, even when it is done mainly in the NIR region, could be observed by the reduction of the surface temperature (during the day), which is in line with the results obtained by Krimpalis and Karamanis [75] and Li et al. [76].

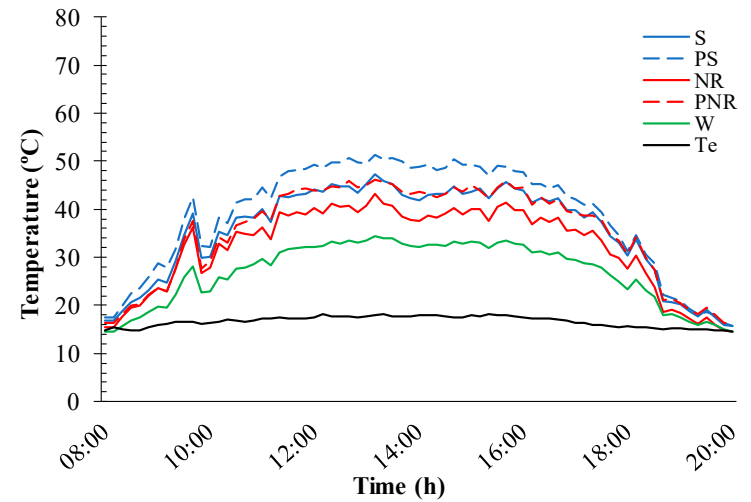

(a)

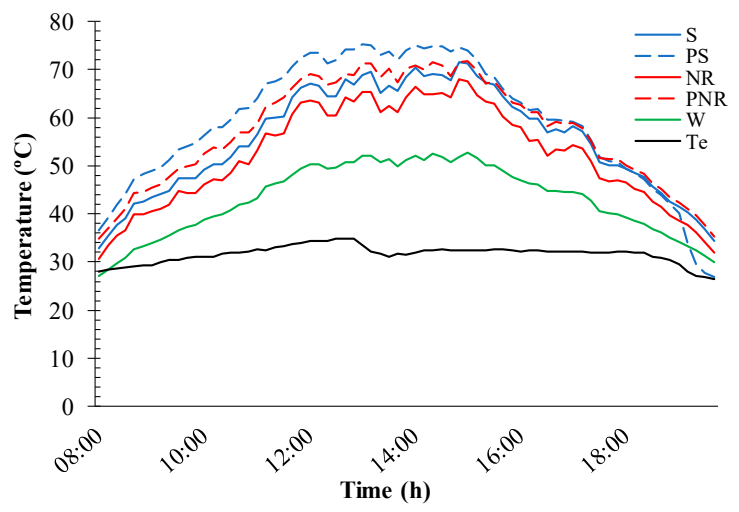

(b)

Figure 9. Surface temperature in: (a) Day of lower temperatures (M12); (b) Day of high temperatures (M13).

A statistical analysis of a representative week of each period (mild and hot) is shown in Figures 10 and 11, respectively. 


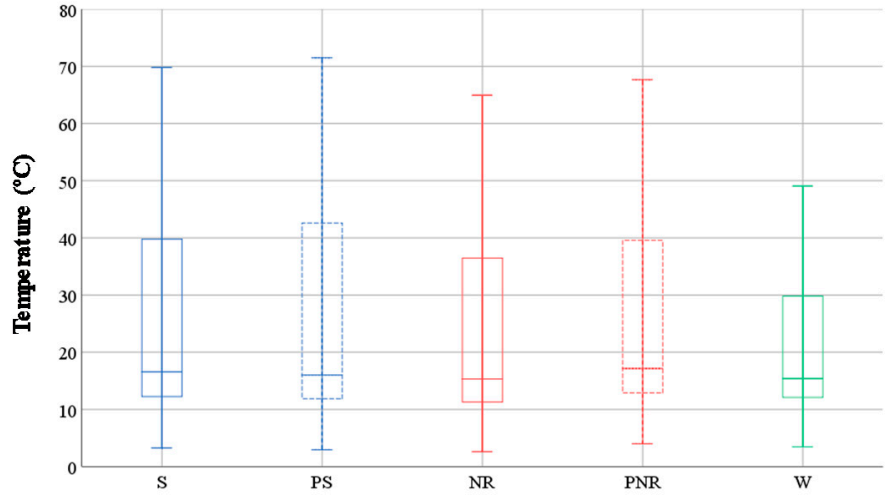

(a)

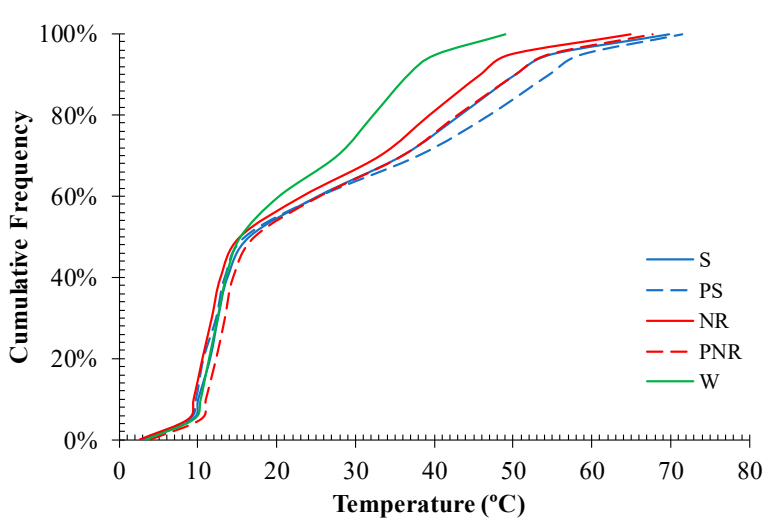

(b)

Figure 10. Surface temperature during a mild week (M12): (a) Box-plots; (b) Cumulative frequencies.

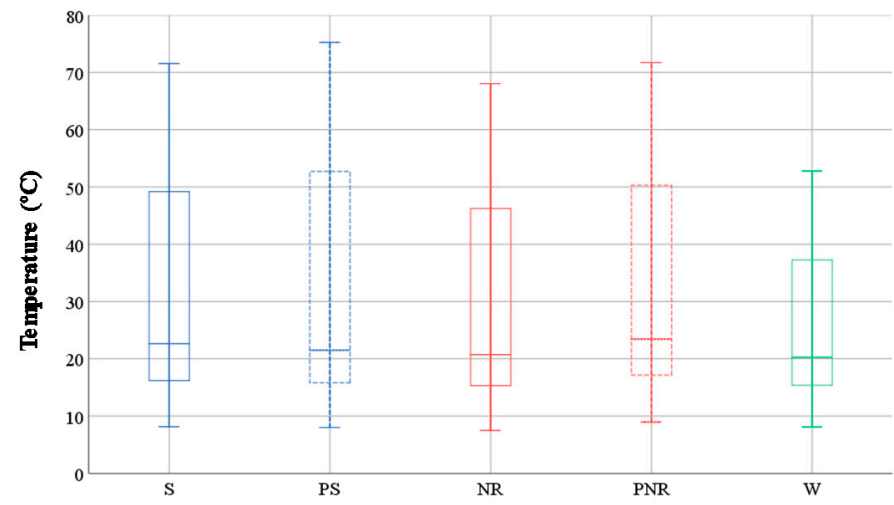

(a)

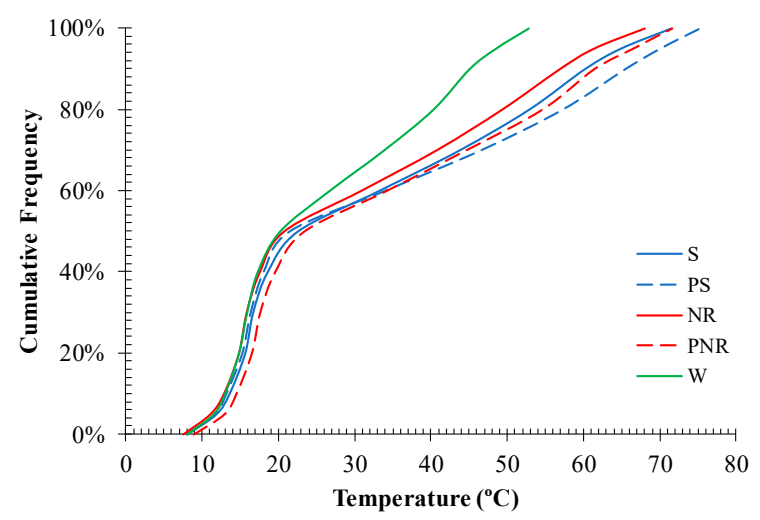

(b)

Figure 11. Surface temperature during a hot week (M13): (a) Box-plots; (b) Cumulative frequencies.

The incorporation of NRP (NR and PNR specimens) promoted, as expected and previously observed, a reduction of the surface temperature, especially for exterior air temperature above $25^{\circ} \mathrm{C}$. Comparing the two analysed weeks, the hot period promoted a greater occurrence of higher surface temperatures, as shown in the cumulative frequencies charts). In addition, specimens with the primer layer (PS and PNR) presented higher temperature compared with the ones without primer. The primer layer reduced the effect of NRP (PNR specimen) since similar behaviour to the standard specimen (S) is observed. As long as the lightness and solar reflectance measured in M12 is similar between the specimens with and without primer, this difference could be related to the internal reflection due to the white primer layer with the NRP and $\mathrm{TiO}_{2}$ particles [34]. Despite the reduction of the surface temperature through the incorporation of NRP in black finishing coatings, the maximum surface temperature is still $\approx 15^{\circ} \mathrm{C}$ higher than the white coating due to the much higher solar reflectance. This fact is related to solar energy in the different spectrum regions. As referred in Equation (2), 53\% of the total solar energy occurs in the NIR region of the solar spectrum. As such, the incorporation of NIR reflective pigments, in this specific region, is responsible for the reduction of a part of the absorbed energy, while the great remaining part is in the visible region (42\%) where the colour is determinant.

In addition, all the specimens presented maximum surface temperature under $80{ }^{\circ} \mathrm{C}$, which meets the ETAG 004 recommendation [13].

\section{Conclusions}

In façade systems, such as ETICS, the final layer properties present a very important role in the overall performance. Solar reflectance is particularly determinant for the thermal 
performance of these systems and contributes decisively to their durability. Taking into account that they are constituted by different materials/layers and, consequently, different thermo-mechanical properties, these systems are subjected to cracking, especially with a high-temperature variation. This fact contributes to compromising the stability and integrity of the different layers and the durability of the entire system.

The incorporation of NIR reflective pigments contributed to maintaining the colour characteristics, such as lightness and chroma, even in dark coatings. In addition, the colour difference after 2 years of ageing in NIR reflective pigments was lower when NRP were incorporated.

The main contribution of NIR reflective pigments is the increase of the solar reflectance and consequently the decrease of surface temperature, even in dark colours, especially for high temperatures (above $25^{\circ} \mathrm{C}$ ). These pigments highly increase the NIR reflectance without affecting the colour (in the visible region).

The application of primer, under the finishing coating, increased the surface temperature, especially for higher exterior temperatures. However, the primer layer contributes to a lower colour difference and solar reflectance variation, which is an important achievement for durability.

A good correlation between the diffuse reflectance (measured with the spectrophotometer) and solar reflectance (measured with the pyranometer) confirmed that the diffuse reflectance of rough coatings contributes to practically all solar reflectance.

Author Contributions: Conceptualization, N.M.M.R., J.M., A.R.S. and R.M.S.F.A.; methodology, J.M., A.R.S. and L.S.; formal analysis, J.M. and A.R.S.; investigation, J.M. and A.R.S.; data curation J.M. and A.R.S.; writing - original draft preparation, J.M. and A.R.S.; writing-review and editing, N.M.M.R., J.M., A.R.S. and R.M.S.F.A.; visualization, N.M.M.R., J.M., A.R.S., R.M.S.F.A. and L.S.; supervision, N.M.M.R. All authors have read and agreed to the published version of the manuscript.

Funding: This research was financially supported by: Base Funding - UIDB/04708/2020 of the CONSTRUCT - Instituto de I\&D em Estruturas e Construções - funded by national funds through the FCT/MCTES (PIDDAC) and by Project PTDC/ECI-CON/28766/2017 - POCI-01-0145-FEDER028766 funded by FEDER funds through COMPETE2020 -Programa Operacional Competitividade e Internacionalização (POCI) and by national funds (PIDDAC) through FCT/MCTES.

Institutional Review Board Statement: Not applicable.

Informed Consent Statement: Not applicable.

Data Availability Statement: The data presented in this study are available on request from the corresponding author.

Acknowledgments: The authors acknowledge Saint-Gobain Weber for the materials supply and IPMA (Portuguese Institute for Sea and Atmosphere) for the weather data sharing.

Conflicts of Interest: The authors declare no conflict of interest.

\section{References}

1. Kisilewicz, T.; Fedorczak-Cisak, M.; Barkanyi, T. Active thermal insulation as an element limiting heat loss through external walls. Energy Build. 2019, 205, 109541. [CrossRef]

2. Pacheco-Torgal, F. Eco-efficient construction and building materials research under the EU Framework Programme Horizon 2020. Constr. Build. Mater. 2014, 51, 151-162. [CrossRef]

3. Pedroso, M.; Flores-Colen, I.; Silvestre, J.; Gomes, M.; Silva, L.; Ilharco, L. Physical, mechanical, and microstructural characterisation of an innovative thermal insulating render incorporating silica aerogel. Energy Build. 2020, 211, 109793. [CrossRef]

4. Vale, H.; Melo, H.; Soares, A.; Flores-Colen, I.; Gomes, M.G. Performance of Industrial Thermal Insulation Renders. In Proceedings of the 9th International Masonry Conference, Guimarães, Portugal, 7-9 July 2014; Lourenço, P.B., Haseltine, B.A., Vasconcelos, G., Eds.; International Masonry Society: Whyteleafe, UK, 2014.

5. Künzel, H.; Künzel, H.; Sedlbauer, K. Long-term performance of External Thermal Insulation Systems (ETICS). Architectura 2006, 5, 11-24.

6. Barreira, E.; de Freitas, V.P. Experimental study of the hygrothermal behaviour of External Thermal Insulation Composite Systems (ETICS). Build. Environ. 2013, 63, 31-39. [CrossRef] 
7. D'Orazio, M.; Cursio, G.; Graziani, L.; Aquilanti, L.; Osimani, A.; Clementi, F.; Yéprémian, C.; Lariccia, V.; Amoroso, S. Effects of water absorption and surface roughness on the bioreceptivity of ETICS compared to clay bricks. Build. Environ. 2014, 77, 20-28. [CrossRef]

8. Nilica, R.; Harmuth, H. Mechanical and fracture mechanical characterization of building materials used for external thermal insulation composite systems. Cem. Concr. Res. 2005, 35, 1641-1645. [CrossRef]

9. Daniotti, B.; Cecconi, F.R.; Paolini, R.; Galliano, R. Durability Evaluation of External Thermal Insulation Composite Systems: Frequency Assessment of Thermal Shocks. In Proceedings of the CIB World Building Congress 2013, Brisbane, QLD, Australia, 5-9 May 2013; Queensland University of Technology (QUT), Ed.;

10. Kvande, T.; Bakken, N.; Bergheim, E.; Thue, J.V. Durability of ETICS with Rendering in Norway-Experimental and Field Investigations. Buildings 2018, 8, 93. [CrossRef]

11. Daniotti, B.; Cecconi, F.R. CIB W080: WG3 Test Methods for Service Life Prediction; CIB Report: Publication 331; Politecnico di Milano: Milan, Italy, 2010; ISBN 978-90-6363-062-1.

12. Spagnolo, S.L.; Daniotti, B. Performance over Time and Durability Assessment of External Thermal Insulation Systems with Artificial Stone Cladding; Research for Development; Springer: Berlin/Heideberg, Germany, 2019; pp. 277-287.

13. EOTA. ETAG 004, Guideline for European Technical Approval of External Thermal Insulation Composite Systems with Rendering; European Organisation for Technical Approvals: Brussels, Belgium, 2013.

14. EOTA. EAD 040083-00-0404, External Thermal Insulation Composite Systems (ETICS) with Rendering; European Organisation for Technical Approvals: Brussels, Belgium, 2019.

15. EAE. European Guideline for the Application of ETICS; European Association for External Thermal Insulation Composite Systems: Baden-Baden, Germany, 2011.

16. Daniotti, B.; Cecconi, F.R.; Paolini, R.; Galliano, R.; Ferrer, J.; Battaglia, L. Durability evaluation of ETICS: Analysis of failures case studies and heat and moisture transfer simulations to assess the frequency of critical events. In Proceedings of the 4th Portuguese Conference on Mortars \& ETICS, Coimbra, Portugal, 29-30 March 2012.

17. ASTM. Standard Tabels for Reference Solar Spectral Irradiances: Direct Normal and Hemispherical on $37^{\circ}$ Tilted Surface; ASTM International: West Conshohocken, PA, USA, 2012.

18. ASTM. ASTM E1918-06 (2015): Standard Test Method for Measuring Solar Reflectance of Horizontal and Low-Sloped Surfaces in the Field; American Society for Testing and Materials: West Conshohocken, PA, USA, 2015.

19. Santamouris, M. Heat Island Research in Europe: The State of the Art. Adv. Build. Energy Res. 2007, 1, 123-150. [CrossRef]

20. Pisello, A.L. State of the art on the development of cool coatings for buildings and cities. Sol. Energy 2017, 144, 660-680. [CrossRef]

21. Mohelnikova, J. Materials for reflective coatings of window glass applications. Constr. Build. Mater. 2009, 23, 1993-1998. [CrossRef]

22. Pacheco-Torgal, F.; Jalali, S. Nanotechnology: Advantages and drawbacks in the field of construction and building materials. Constr. Build. Mater. 2011, 25, 582-590. [CrossRef]

23. Borsoi, G.; Parracha, J.; Caiado, P.; Flores-Colen, I.; Dionísio, A.; Veiga, R. Assessing Water Resistance and Surface Properties of ETICS. In Proceedings of the XV International Conference on Durability of Building Materials and Components (DBMC 2020), Barcelona, Spain, 20-23 October 2020; Serrat, C., Casas, J.R., Gibert, V., Eds.;

24. Levinson, R.; Berdahl, P.; Akbari, H. Solar spectral optical properties of pigments-Part II: Survey of common colorants. Sol. Energy Mater. Sol. Cells 2005, 89, 351-389. [CrossRef]

25. Baneshi, M.; Maruyama, S.; Komiya, A. The Effects of Using Some Common White Pigments on Thermal and Aesthetic Performances of Pigmented Coatings. J. Therm. Sci. Technol. 2009, 4, 131-145. [CrossRef]

26. Baneshi, M.; Gonome, H.; Komiya, A.; Maruyama, S. The effect of particles size distribution on aesthetic and thermal performances of polydisperse $\mathrm{TiO}_{2}$ pigmented coatings: Comparison between numerical and experimental results. J. Quant. Spectrosc. Radiat. Transf. 2012, 113, 594-606. [CrossRef]

27. Piri, N. Application of Multi Flux Model to Predict Optical Performance of Titanium Dioxide Nanopigments. Int. J. Nanosci. Nanotechnol. 2019, 15, 27-36.

28. Kinoshita, S.; Yoshida, A. Investigating performance prediction and optimization of spectral solar reflectance of cool painted layers. Energy Build. 2016, 114, 214-220. [CrossRef]

29. Jose, S.; Joshy, D.; Narendranath, S.B.; Periyat, P. Recent advances in infrared reflective inorganic pigments. Sol. Energy Mater. Sol. Cells 2019, 194, 7-27. [CrossRef]

30. Xiang, B.; Yin, X.; Zhang, J. A novel cool material: ASA (acrylonitrile-styrene-acrylate) matrix composites with solar reflective inorganic particles. Compos. Sci. Technol. 2017, 145, 149-156. [CrossRef]

31. Xiang, B.; Zhang, J. Effects of content and surface hydrophobic modification of BaTiO3 on the cooling properties of ASA (acrylonitrile-styrene-acrylate copolymer). Appl. Surf. Sci. 2018, 427, 654-661. [CrossRef]

32. Song, J.; Qin, J.; Qu, J.; Song, Z.; Zhang, W.; Xue, X.; Shi, Y.; Zhang, T.; Ji, W.; Zhang, R.; et al. The effects of particle size distribution on the optical properties of titanium dioxide rutile pigments and their applications in cool non-white coatings. Sol. Energy Mater. Sol. Cells 2014, 130, 42-50. [CrossRef]

33. Xie, N.; Li, H.; Abdelhady, A.; Harvey, J. Laboratorial investigation on optical and thermal properties of cool pavement nanocoatings for urban heat island mitigation. Build. Environ. 2019, 147, 231-240. [CrossRef] 
34. Zhou, A.; Yu, Z.; Chow, C.L.; Lau, D. Enhanced solar spectral reflectance of thermal coatings through inorganic additives. Energy Build. 2017, 138, 641-647. [CrossRef]

35. Uemoto, K.L.; Sato, N.M.; John, V.M. Estimating thermal performance of cool colored paints. Energy Build. 2010, 42, 17-22. [CrossRef]

36. Daniotti, B.; Diamanti, M.V.; Luongo, N.; Massari, S.; Pedeferri, M.P.; Spagnolo, S.L. Characterization of durability and photocatalytic properties of TiO2 cement-based materials. In Materials for Energy, Efficiency and Sustainability: TechConnect Briefs 2018; TechConnect Briefs: Washington, DC, USA, 2018; Volume 2, pp. 203-206. ISBN 978-0-9975117-9-6.

37. Borsoi, G.; Esteves, C.; Flores-Colen, I.; Veiga, R. Effect of Hygrothermal Aging on Hydrophobic Treatments Applied to Building Exterior Claddings. Coatings 2020, 10, 363. [CrossRef]

38. Piri, N.; Shams-Nateri, A.; Mokhtari, J. Solar spectral performance of nanopigments. Sol. Energy Mater. Sol. Cells 2017, 162, 72-82. [CrossRef]

39. Daniotti, B.; Spagnolo, S.L. Service life prediction for buildings' design to plan a sustainable building maintenance. In Proceedings of the Portugal SB 2007-Sustainable Construction, Materials and Practices: Challenge of the Industry for the New Millennium, Lisbon, Portugal, 12-14 September 2007; pp. 515-521.

40. Grynning, S.; Gradeci, K.; Gaarder, J.E.; Time, B.; Lohne, J.; Kvande, T. Climate Adaptation in Maintenance Operation and Management of Buildings. Buildings 2020, 10, 107. [CrossRef]

41. Stagrum, A.E.; Andenæs, E.; Kvande, T.; Lohne, J. Climate Change Adaptation Measures for Buildings-A Scoping Review. Sustainabiliy 2020, 12, 1721. [CrossRef]

42. Berdahl, P.; Akbari, H.; Levinson, R.; Miller, W.A. Weathering of roofing materials-An overview. Constr. Build. Mater. 2008, 22, 423-433. [CrossRef]

43. Susca, T. Enhancement of life cycle assessment (LCA) methodology to include the effect of surface albedo on climate change: Comparing black and white roofs. Environ. Pollut. 2012, 163, 48-54. [CrossRef] [PubMed]

44. Sleiman, M.; Chen, S.; Gilbert, H.E.; Kirchstetter, T.W.; Berdahl, P.; Bibian, E.; Bruckman, L.S.; Cremona, D.; French, R.H.; Gordon, D.A.; et al. Soiling of building envelope surfaces and its effect on solar reflectance-Part III: Interlaboratory study of an accelerated aging method for roofing materials. Sol. Energy Mater. Sol. Cells 2015, 143, 581-590. [CrossRef]

45. Ferrari, C.; Touchaei, A.G.; Sleiman, M.; Libbra, A.; Muscio, A.; Siligardi, C.; Akbari, H. Effect of aging processes on solar reflectivity of clay roof tiles. Adv. Build. Energy Res. 2014, 8, 28-40. [CrossRef]

46. ASTM. Standard Practice for Laboratory Soiling and Weathering of Roofing Materials to Simulate Effects of Natural Exposure on Solar Reflectance and Thermal Emittance; ASTM International: West Conshohocken, PA, USA, 2018.

47. Akbari, H.; Levinson, R.; Stern, S. Procedure for measuring the solar reflectance of flat or curved roofing assemblies. Sol. Energy 2008, 82, 648-655. [CrossRef]

48. Levinson, R.; Akbari, H.; Berdahl, P. Measuring solar reflectance-Part II: Review of practical methods. Sol. Energy 2010, 84, 1745-1759. [CrossRef]

49. Levinson, R.; Egolf, M.; Chen, S.; Berdahl, P. Experimental comparison of pyranometer, reflectometer, and spectropho-tometer methods for the measurement of roofing product albedo. Sol. Energy 2020, 206, 826-847. [CrossRef]

50. Hukseflux, T.S. Pyranometer Products. Available online: http://www.hukseflux.com/product_group/pyranometer (accessed on 22 April 2016).

51. ISO. ISO 9060:2018-Solar Energy—Specification and Classification of Instruments for Measuring Hemispherical Solar and Direct Solar Radiation; International Organization for Standardization: Geneva, Switzerland, 2018.

52. ASTM. Standard Test Method for Solar Absorptance, Reflectance, and Transmittance of Materials Using Integrating Spheres; ASTM International: West Conshohocken, PA, USA, 2020.

53. ISO. EN ISO/CIE 11644: Colorimetry Part 3: CIE Tristimulus Values; CIE International Commission on Illumination: Geneva, Switzerland, 2019.

54. Hanson, A.R. 1-What is colour? In Colour Design, 2nd ed.; Best, J., Ed.; Woodhead Publishing: Cambridge, UK, $2012 ;$ pp. 3-21.

55. Sattar, S. Characterizing Color with Reflectance. J. Chem. Educ. 2019, 96, 1124-1128. [CrossRef]

56. Sharma, G.; Wu, W.; Dalal, E.N. The CIEDE2000 color-difference formula: Implementation notes, supplementary test data, and mathematical observations. Color Res. Appl. 2004, 30, 21-30. [CrossRef]

57. Brainard, D.H. Color Appearance and Color Difference Specification. Sci. Color 2003, 191-216. [CrossRef]

58. Weatherall, I.L.; Coombs, B.D. Skin Color Measurements in Terms of CIELAB Color Space Values. J. Investig. Dermatol. 1992, 99, 468-473. [CrossRef]

59. Revel, G.M.; Martarelli, M.; Emiliani, M.; Gozalbo, A.; Orts, M.J.; Bengochea, M.Á.; Delgado, L.G.; Gaki, A.; Katsiapi, A.; Taxiarchou, M.; et al. Cool products for building envelope-Part I: Development and lab scale testing. Sol. Energy 2014, 105, 770-779. [CrossRef]

60. Coser, E.; Moritz, V.F.; Krenzinger, A.; Ferreira, C.A. Development of paints with infrared radiation reflective properties. Polimeros 2015, 25, 305-310. [CrossRef]

61. Rossi, S.; Lindmark, H.; Fedel, M. Colored Paints Containing NIR-Reflective Pigments Exposed to Accelerated Ultraviolet Radiation Aging with Possible Application as Roof Coatings. Coatings 2020, 10, 1135. [CrossRef]

62. Cozza, E.; Alloisio, M.; Comite, A.; Di Tanna, G.; Vicini, S. NIR-reflecting properties of new paints for energy-efficient buildings. Sol. Energy 2015, 116, 108-116. [CrossRef] 
63. Mokrzycki, W.; Tatol, M. Color difference Delta E-A survey. Mach. Graph. Vis. 2011, 20, 383-411.

64. Ihara, T.; Jelle, B.P.; Gao, T.; Gustavsen, A. Accelerated aging of treated aluminum for use as a cool colored material for facades. Energy Build. 2016, 112, 184-197. [CrossRef]

65. Paolini, R.; Zani, A.; Poli, T.; Antretter, F.; Zinzi, M. Natural aging of cool walls: Impact on solar reflectance, sensitivity to thermal shocks and building energy needs. Energy Build. 2017, 153, 287-296. [CrossRef]

66. Pisello, A.L.; Fortunati, E.; Fabiani, C.; Mattioli, S.; Dominici, F.; Torre, L.; Cabeza, L.F.; Cotana, F. PCM for improving polyurethane-based cool roof membranes durability. Sol. Energy Mater. Sol. Cells 2017, 160, 34-42. [CrossRef]

67. Gobakis, K.; Kolokotsa, D.; Maravelaki-Kalaitzaki, N.; Perdikatsis, V.; Santamouris, M. Development and analysis of ad-vanced inorganic coatings for buildings and urban structures. Energy Build. 2015, 89, 196-205. [CrossRef]

68. Santamouris, M. Cooling the cities-A review of reflective and green roof mitigation technologies to fight heat island and improve comfort in urban environments. Sol. Energy 2014, 103, 682-703. [CrossRef]

69. Rosso, F.; Pisello, A.L.; Jin, W.; Ghandehari, M.; Cotana, F.; Ferrero, M. Cool Marble Building Envelopes: The Effect of Aging on Energy Performance and Aesthetics. Sustainability 2016, 8, 753. [CrossRef]

70. Vox, G.; Maneta, A.; Schettini, E. Evaluation of the radiometric properties of roofing materials for livestock buildings and their effect on the surface temperature. Biosyst. Eng. 2016, 144, 26-37. [CrossRef]

71. Gonome, H.; Baneshi, M.; Okajima, J.; Komiya, A.; Maruyama, S. Controlling the radiative properties of cool black-color coatings pigmented with $\mathrm{CuO}$ submicron particles. J. Quant. Spectrosc. Radiat. Transf. 2014, 132, 90-98. [CrossRef]

72. Ganguly, A.; Chowdhury, D.; Neogi, S. Performance of Building Roofs on Energy Efficiency-A Review. Energy Procedia 2016, 90, 200-208. [CrossRef]

73. Zinzi, M.; Carnielo, E.; Rossi, G. Directional and angular response of construction materials solar properties: Characteri-sation and assessment. Sol. Energy 2015, 115, 52-67. [CrossRef]

74. Meola, C.; Boccardi, S.; Carlomagno, G.M. (Eds.) Infrared Thermography in the Evaluation of Aerospace Composite Materials. In Infrared Thermography in the Evaluation of Aerospace Composite Materials; Woodhead Publishing: Cambridge, UK, 2017 ; pp. 57-83.

75. Krimpalis, S.; Karamanis, D. A novel approach to measuring the solar reflectance of conventional and innovative building components. Energy Build. 2015, 97, 137-145. [CrossRef]

76. Li, H.; Harvey, J.; Kendall, A. Field measurement of albedo for different land cover materials and effects on thermal performance. Build. Environ. 2013, 59, 536-546. [CrossRef] 